\title{
Temporal trends in reproductive performance in Irish dairy herds and associated risk factors
}

\author{
John F. Mee \\ Teagasc, Dairy Production Research Department, Dairy Production Research Centre, Moorepark, Fermoy, Co Cork, Ireland.
}

Irish dairy herd fertility has been declining since the 1980s. The extent, nature and causes of this decline in fertility and the current status of Irish dairy herd fertility were described. An increase in calving interval of approximately one day per year has been recorded. The principal components of this trend have been an increased incidence of postpartum endocrinopathies, reduced expression of oestrus and a fall in conception rate. Both submission rate and calving-to-service interval have increased slightly over time. Significant risk factors associated with these trends have been strain substitution within the HolsteinFriesian breed and single trait selection for milk production. Critically, these changes have been reflected in loss of body condition. Contributory factors included increased herd size and possibly increased use of DIYAI. The most recent Irish study showed that $48 \%$ of cows conceived to first service and $14 \%$ of cows were not pregnant at the end of the industryaverage 15-week spring breeding season. However, the top quartile of herds achieved a first-service conception rate of 59\%, illustrating the wide variation between herds. These phenotypic trends were attributed to both genetic and environmental factors and their interactions. Recent Irish dairy herd fertility performance falls short of the targets set for seasonal compact calving.

Irish Veterinary Journal

Volume 57: 158 - 166,2004

\section{Introduction}

Efficient milk production in Irish dairy herds is dependent upon producing the maximum amount of milk from grazed grass. To co-ordinate peak milk yield with maximum grass growth, cows must calve compactly before turn-out to pasture in the spring. Irish dairy farmers aim to get the maximum number of cows pregnant in a short breeding season and in the past have done so successfully. However, in recent years, changes in our farming systems have led to a decline in dairy herd fertility.

\section{Correspondence:}

\section{John F. Mee}

Teagasc, Dairy Production Research Department, Dairy Production Research Centre, Moorepark,

Fermoy, Co. Cork, Ireland.

Tel: +3532542387

Fax: +3532542340

E-mail: jmee@moorepark.teagasc.ie

\author{
Key words \\ Cattle, \\ Fertility, \\ Genetics, \\ Nutrition, \\ Management.
}

\section{Materials and methods}

Reproductive performance is defined here by the standard phenotypic indices of herd fertility (O'Farrell, 1992) and culling. The limitations of any one of these indices to adequately describe herd fertility, the influences of both genetic and environmental factors and the biases of management decisions and inadvertent data censoring are recognised. Thus, while calving interval data are readily available from milk records, they are only available for cows that conceive and calve again. The Irish data examined here originated in commercial dairy herds and in An Foras Talúntais and Teagase research herds. Research herd data came from experimental studies and retrospective analyses of herd fertility databases. Commercial herd data were generated from computerised herd datasets (DairyMIS, a recorder-based computerised data management system, and the National Farm Survey), milk recording schemes, experimental field studies and questionnaire surveys. These sources do not constitute a standardised recording of data from a representative sample of the national herd. Rather, 


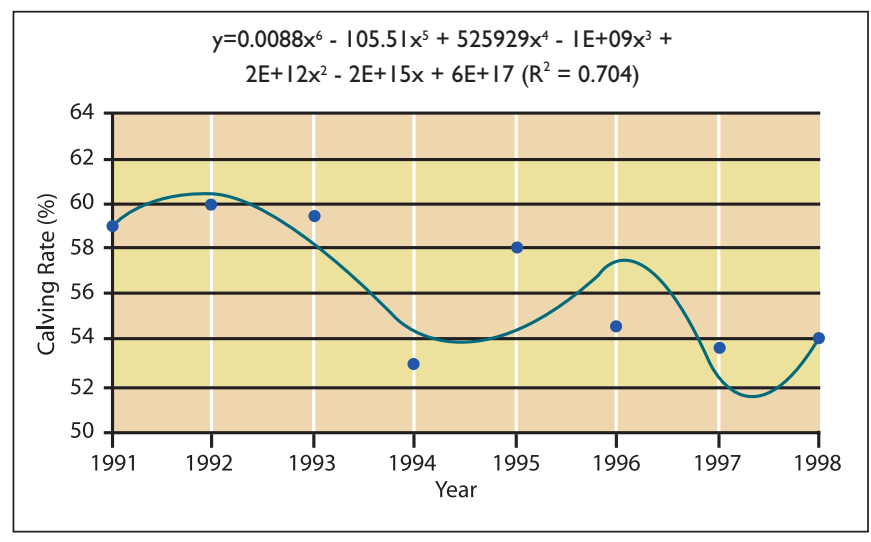

FIGURE I: Calving rate to first service in DairyMIS herds, I99| to 1998. (Source: Mee et al., 1999).

the fragmented nature of these data sources reflects the absence of a national database on herd fertility.

Relationships between variables were examined by least squares regression analysis and the results presented graphically in MS Excel $^{\mathrm{TM}}$ (Microsoft Corporation, 1997). The best-fit trend line was chosen from sixth order polynomial regressions as having the highest coefficient of determination $\left(\mathrm{R}^{2}\right)$.

\section{Results}

Extent of the decline in herd fertility

Surveys of Irish dairy cattle showed that herd fertility was high throughout the 1960s and 1970s. The majority of these studies reported calving rates, with a small number reporting conception rates or non-return rates. Calving rates to first service by artificial insemination varied between $60 \%$ and $69 \%$, calving intervals between 357 and 380 days and infertile rates between $2 \%$ and $10 \%$. These studies collected data on between approximately 2,000 and 8,000 cows per study (O'Farrell et al., 1997).

The first indication of a significant decline in Irish dairy herd fertility was detected in a retrospective analysis of data from Teagasc research herds. The highest conception rate to first service was recorded in 1980 as $67 \%$ and it declined to $59 \%$ in 1988 (Fair et al., 1991). Subsequent studies in commercial herds in the 1990s confirmed this phenotypic trend (Figure 1) when calving rate to first service declined significantly by $0.7 \%$ to $0.9 \%$ per year (O'Farrell and Crilly, 2001; Mee et al., 1999). However, the decline in calving rate to all services was smaller (0.5\% per year: Mee et al., 1999).

These trends recorded in research herds and DairyMIS herds may or may not be representative of trends in the national dairy cow population. However, they are consistent with fertility data from cows in milk recording herds during the 1990s (Figure 2). These data show an increase in calving interval of 0.9 days per year (1993: 389 days v. 1999: 395 days) and a decrease in reappearance rate between first and second lactation of $1 \%$ per year (1993:80.4\% v. 1999:73.2\%).

Furthermore, the genetic data from Irish progeny test bulls

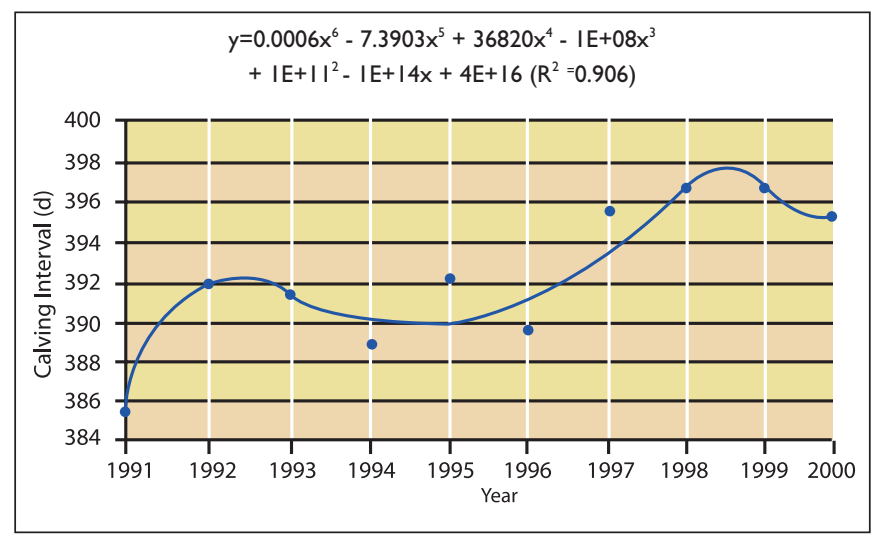

FIGURE 2: Calving interval in Irish milk recording herds, 1990 to 1999. (Source: ICBF, 2002).

show a similar decline in survival and calving interval proofs in the 1980s and 1990s (ICBF, 2002). Overall, these data suggest that the decline in dairy herd fertility began during the $1980 \mathrm{~s}$ with a reduction of $0.5 \%$ to $0.9 \%$ per year in conception rate or calving rate and an increase in calving interval of approximately one day per year.

These trends are not unique to Irish herds. Similar trends have been reported worldwide: in the UK (Esslemont and Kossaibati, 2002; Royal et al., 2000), France (Boichard et al., 2002; Chevallier and Humblot, 1998), Germany (Gorlach, 1988), Spain (Lopez-Gatius, 2003), the Netherlands (Hoekstra et al., 1994), Scandinavia (Berglund and Philippson, 2001), Israel (Weller and Ezra, 1997), Australia (M. Haile-Mariam, Institute of Land and Food Resources, University of Melbourne, personal communication) and North America (Rajala-Schultz and Fraser, 2003; Washburn et al., 2002; Lucy, 2001). Even in New Zealand, where cow fertility has been assumed to be high, recent survey data indicate conception rates are lower (first AI conception rate of 53\%) than in previous years (Xu and Burton, 2000). In addition, in the UK, fertility in maiden heifers selected for milk production declined from 1981 to 1998 (Pryce et al., 2002).

Contrary to this profile of declining herd fertility, Silva et al. (1992) did not find a trend in calving interval in data covering fifty-two years (1923 to 1974) from dairy herds in Florida. Similarly, Whitaker (2002) suggested that declining herd fertility has been happening only on some farms in the UK but not on all farms. These reports may reflect significant regional or herd variation in the occurrence of the risk factors outlined hereunder.

\section{Nature of the decline in herd fertility}

The reproductive performance of a herd is determined by the onset of postpartum cyclicity leading to a dominant (ovulatory) follicle, expression/detection of oestrus, conception rate and subsequent loss. While a delay in the onset of puberty has not been documented over time, significant differences now exist between strains of Holstein-Friesians under the same Irish farm management conditions (McGrath et al., 2001). 


\section{TABLE 1: Comparison of atypical luteal activity post partum in Irish dairy cows in 1982 (Fagan and Roche, 1986) and in 2002 (Teagasc, unpublished)}

\begin{tabular}{|c|c|c|}
\hline Atypical progesterone profile & 1982 (463 cows) & 2002 (396 cows) \\
\hline Delayed onset of ovulation (\%) ${ }^{\mathrm{a}}$ & 7 & 15 \\
\hline Prolonged luteal phase $(\%)^{b}$ & 3 & 10 \\
\hline Anovulation following cyclicity $(\%)^{\mathrm{c}}$ & 3 & 1 \\
\hline TOTAL (\%) & 13 & 26 \\
\hline \multicolumn{3}{|c|}{$\begin{array}{l}\text { a } 1982 \text { (to day } 50) ; 2002 \text { (to day } 45),{ }^{b} 1982 \text { ( } \geq 20 \text { days); } 2002 \text { ( } \geq 19 \text { days), } \\
{ }^{\text {c }} 1982 \text { ( } \geq 14 \text { days); } 2002 \text { ( } \geq 12 \text { days). }\end{array}$} \\
\hline
\end{tabular}

Postpartum endocrinopathies

There are compelling data from the UK demonstrating significant changes over the last two decades in the pattern, but not the onset, of postpartum luteal activity in dairy cows (Royal et al., 2000). Recent large-scale studies from abroad indicate between $40 \%$ and $50 \%$ of dairy cows now have abnormal luteal profiles post partum (Mann, 2002; Opsomer et al., 2000). In addition, negative genetic (Veerkamp et al., 2000) and phenotypic relationships have been demonstrated between milk yield and resumption of cyclicity post partum (Taylor et al., 2000). Comparison of recent Irish data (Teagasc, unpublished) with Irish data from 20 years ago (Fagan and Roche, 1986) indicates an increased incidence of both abnormal milk progesterone profiles and delayed onset of luteal activity (Table 1).

\section{Suboestrus}

Concern has been expressed over the apparent decline in efficiency of detection of oestrus in recent years (Nebel and Mowrey, 2000). Data from New Zealand (Burton et al., 1999) show a significant decline in 21 -day submission rate of $0.5 \%$ per year from $1973(94 \%)$ to $1996(82 \%)$. This may reflect a decrease in efficiency of detection of oestrus or an increase in anoestrus. Data from the UK and North America show a slight decline in efficiency of detection of oestrus during the 1980s and 1990s (Esslemont and Kossaibati, 2002; Washburn et al., 2002). One component of this decline may be a reduction in the intensity of expression of oestrus. A comparison of the average duration of oestrus in pasture-based, spring-calving Irish dairy cows between the 1970s (9.3 h: O'Farrell, 1992) and 25 years later $(8.4 \mathrm{~h}$ : Mee et al., 2002a) suggests no difference in the duration of oestrus. However, comparison of the average number of mounts per oestrus reveals a decline from, on average, 52 mounts to 12 mounts. High genetic merit and high milk yield have been associated with reduced expression of oestrus at first ovulation (Westwood et al., 2002). Jorritsma et al. (2000) suggested that reduced expression of oestrus may be caused by low blood cholesterol concentrations resulting in low blood oestrogen concentrations in cows with fatty liver. Notwithstanding these findings, with good management (five observations/day for detection of oestrus, with tail paint and prebreeding-season veterinary examinations), submission rates (24-day) approaching $100 \%$ were achieved in Teagasc experimental herds (Horan et al., 2003; Quinn et al., 2002). Similarly, submission rates increased slightly during the 1990s in DairyMIS herds (Mee et al., 1999), possibly due to increased adoption of prebreeding-season detection of oestrus and early treatment of anoestrous cows (Mee et al., 2002). Overall, these data suggest that efficiency of detection of oestrus and submission rates have not declined in Irish herds. However, increased awareness of poor fertility and increased veterinary intervention may be masking reduced expression of oestrus.

Poor quality of oocyte or embryo

The most recent data from high-yielding Holstein-Friesian cows indicate that fertilisation rate $(90 \%)$ has not declined (Sartori et al., 2002). Thus, it is assumed that the major components of the decline in conception rate are compromised developmental competence of oocyte and/or of embryo leading to early embryonic mortality. It is not clear what are the underlying mechanisms. Working physiological models include greater hepatic metabolism of steroid hormones in high-yielding cows with consequent asynchrony between the onset of oestrus and ovulation (Bloch et al., 2001), increased ovulation rate (Wiltbank et al., 2000), and compromised development of early oocytes (Snijders et al., 2000) and of embryos (Mann et al., 1999). Severe negative energy balance (NEB) immediately post partum may alter gene expression in the pre-antral follicle resulting in a dysfunctional mature follicle with resultant poor oocyte quality and a subfunctional corpus luteum during the subsequent breeding season (Britt, 1994). Metabolic nonadaptation in early lactation, as evidenced in the circulation by elevated concentrations of ammonia, urea and NEFAs and lower concentrations of IGF-I, may detrimentally affect the quality of oocyte and corpus luteum (Jorritsma et al., 2003a,b). Underlying these models may be alteration of the somatotropic-gonadotropic axis in favour of increased somatotropin and reduced insulin secretion resulting from increased milk production and reduced fat deposition through single trait selection.

\section{Fertility of sires}

It is unknown whether a concomitant decline in male fertility occurred over the last two decades but this trend has been reported in humans, partially attributed to endocrine disrupting compounds (EDC). Inbreeding has also been implicated in declining dairy cow fertility in North America.

\section{Causes of the decline in herd fertility}

Putative risk factors may be classified as genetic (strain substitution, selection for milk yield, inbreeding), nutritional $(\mathrm{NEB})$, managemental (calving pattern, herd size, detection of oestrus, feeding management, synchronisation of oestrus, do-it- 


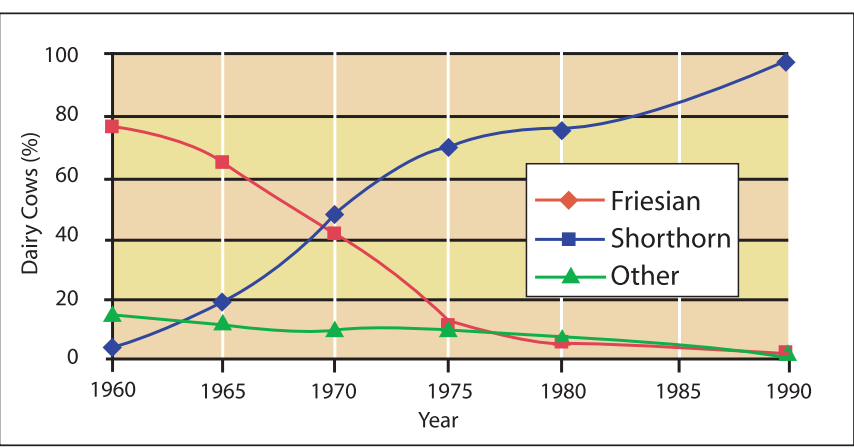

FIGURE 3: Breed composition (\%) of the Irish national dairy cow population between 1960 and 1990 .

(Sources: Cunningham, 1976; EEC, 1989; Drennan and Power, 1993).

yourself artificial insemination (DIYAI), fixed-time AI (FTAI), milking frequency, bovine somatotropin (bST), environmental (reproductive diseases, housing conditions, EDCs, global warming) and their interactions. Some of these factors are of limited relevance in Irish dairy herds (FTAI, milking frequency, bST, confinement, global warming), whereas others are of unknown relevance (inbreeding, EDCs) and the remainder are most relevant.

Strain substitution

Prior to the 1960s, the dairy Shorthorn was the predominant breed in Irish dairy herds (Figure 3). Shorthorns were gradually replaced by British Friesians, which predominated in the national herd during the 1970s and 1980s. In 1974, the Department of Agriculture licensed the first importation of semen from Holstein bulls. By the 1980s the British Friesian was rapidly being replaced through the importation of European and North American Holstein-Friesian (NAHF) cows, semen and embryos. This trend was accelerated following the introduction of the single European market in 1992. Thus, the proportion of NAHF genetics increased from less than $10 \%$ in 1977 to $80 \%$ in 1998 in the British Isles (Figure 4). This compares with $24 \%$ and almost $100 \%$ in the New Zealand and

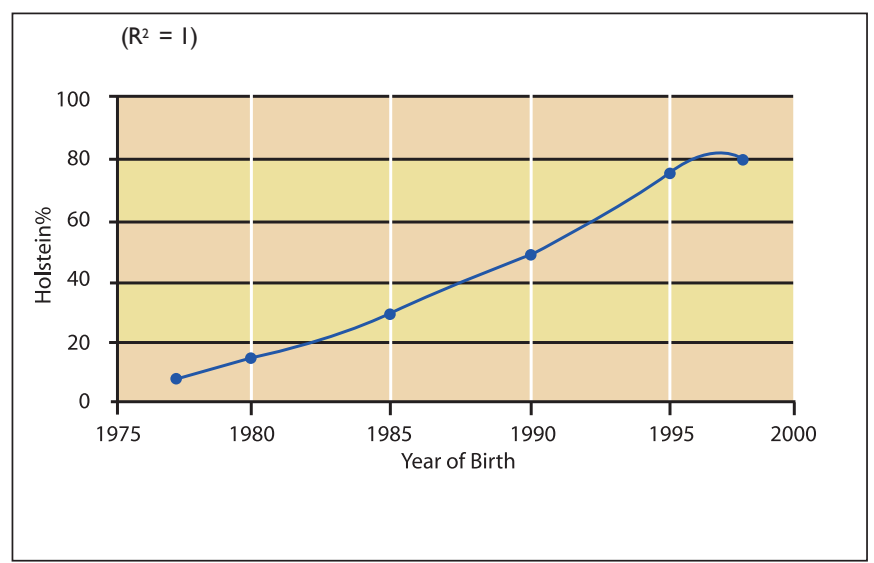

FIGURE 4: Percentage of Holstein genes in cows registered by Holstein UK and Ireland (HUKI) between 1977 and 1998. (Sources: Simm, 1998; Dillon and Veerkamp, 200I).
Dutch national dairy herds, respectively (Dillon and Veerkamp, 2001).

As this was occurring, it was concluded that the available data did not support or refute the contention that "holsteinisation" would reduce Irish herd fertility (More O'Ferrall, 1984). However, Irish experiments in the 1990s showed poorer reproductive performance in imported Holstein-Friesians of high genetic merit than in those of medium genetic merit (Snijders et al., 2001). The introduction of NAHF genetics to dairy cow populations worldwide has been associated with reduced herd fertility, particularly in seasonal-calving dairy industries (Harris et al., 2001; Royal et al., 2000; Hoekstra et al., 1994). This impact has been greatest in dairy industries where Holstein-Friesians comprise over $90 \%$ of the dairy cow population, such as North America, the Netherlands, the UK and Ireland. There are, nonetheless, reports of no adverse relationship between genetic merit for milk production and dairy herd fertility (Mayne et al., 2002; Morton et al., 2000).

Single trait selection

Although selection for milk production alone had traditionally been practised in Irish dairy herds, the rate of genetic gain was low $(0.5 \%$ per year $)$ up to the mid-1980s. However, since 1985 , with accelerated strain substitution, this has increased markedly to over $1 \%$ per year (Evans et al., 2002). There is a qualified genetic relationship between increasing genetic merit for higher milk yield (Figure 5) and reducing fertility whereby management and environment affect the relationship. For example, relatively higher-producing cows tend to be inseminated later than their lower-producing herdmates (Ouweltjes et al., 1996). In Ireland, this relationship is affected not merely by genetic merit for milk production but also by concurrent strain substitution. Hence, the decline in fertility cannot solely be attributed to the increase in yield (Figure 6). In Ireland, the introduction of the milk quota resulted in excess dairy cows being retained in herds with consequent lower phenotypic milk yields per cow than their genetic potential might indicate as reflected in the temporal trend in genetic and

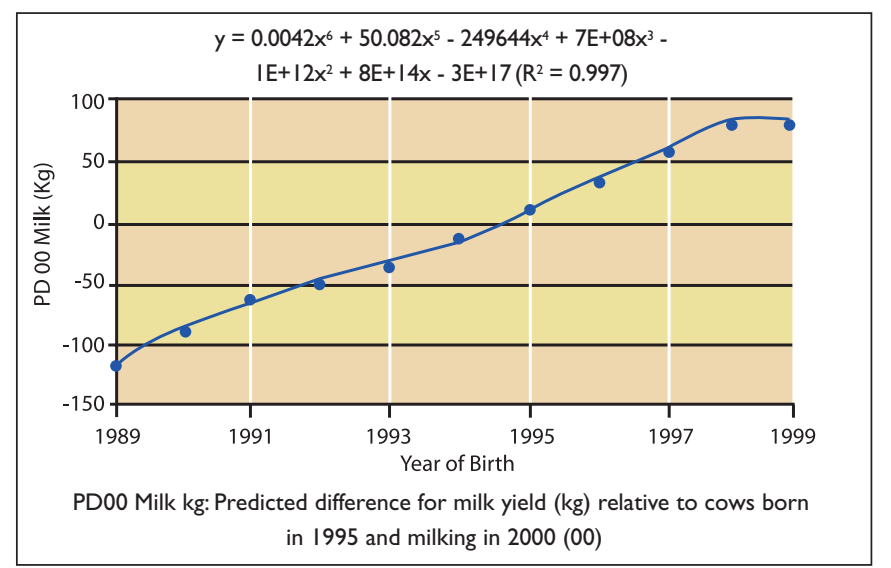

FIGURE 5: Genetic merit for milk yield in Irish dairy cows between 1989 and 1999.

(Source: ICBF, 2002) 


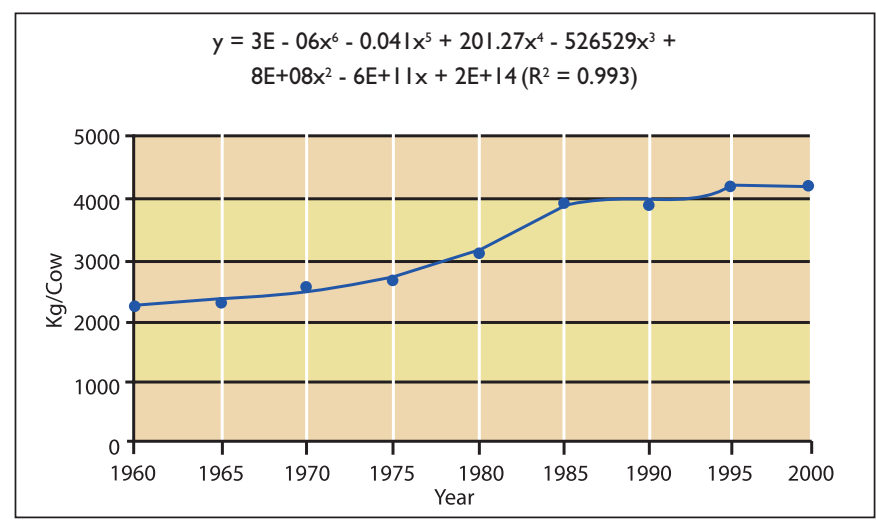

FIGURE 6: Average phenotypic milk yield per cow in Irish dairy herds between 1960 and 2000. (Source: EEC, 1977-200I).

phenotypic yield during the 1980s (Figures 5 and 6). Introduction of the milk quota also resulted in a low culling rate (15\%) by international standards but infertility is the most common reason for culling (24\%) and has increased significantly over time (Mee et al., 1999; O'Farrell et al., 1997). Selection for milk production alone has consistently been accompanied by reduced herd fertility due to the negative genetic correlations at cow level between these variables (Evans et al., 2002; Pryce and Veerkamp, 2001).

\section{Negative energy balance}

In early lactation milk output increases faster than dry matter intake. With selection on milk production alone, the correlated increase in dry matter intake is insufficient to balance the increased nutrient requirements; hence, the extent and duration of NEB is exacerbated. In Ireland, the introduction of milk quotas in 1984 led to the practices of drying off early and restricting feeding prior to the spring breeding season to avoid supplying over quota as most farmers retained excess cows for their quota. These practises resulted in excess body condition score (BCS) at calving and increased subsequent BCS loss. High BCS during the dry period is often associated with a more severe and longer-lasting NEB in early lactation (Jorritsma et al., 2003b). A greater dependence was placed on extending the grazing season and maximising utilisation of grazed grass as a major source of dietary energy to cut costs as income was restricted by quota. Concurrently, the genetic trend for BCS in sires used in Irish dairy herds declined consistently in the 1980s and 1990s (Cromie, 2002). Along with increased milk yield over time, there have been changes in the lactation curve of Irish dairy cows; the slope is now steeper, peak week of lactation is later (1978, 5.5 weeks; 1999, 10.3 weeks) and lactation length is longer (Quinn et al., 2003). These changes in management, nutrition and genetics have led to an increased risk of deeper and more prolonged NEB in early lactation. This may be reflected in the greater decline in calving rate to first service compared to subsequent services reported during the 1990s (Mee et al., 1999). Recent data from Irish commercial dairy herds have shown that poor BCS $(<2.75)$ at first service or excess BCS loss $(>0.5)$ between calving and first service are significantly associated with reduced submission, conception and pregnancy rates (Buckley et al., 2003a).

\section{Breeding pattern}

Throughout the 1990s the farming media highlighted the decline in fertility in Irish dairy herds. This could have influenced dairy farmers to prolong the calving-to-first service interval in the hope that this would improve conception rate but with a possible increase in the calving interval. Data from France indicate this policy was adopted there when conception rates declined and calving interval increased (Chevallier and Humblot, 1998). Irish data show a small increase in calving-toservice interval (68 v. 71 days) between herd surveys in 196970 (Langley, 1986) and in 1999 (Buckley et al., 2000). However, the proportion of cows first served more than three months postpartum increased from the 1980s (12\%, Fair et al., $1991)$ to the 1990s (21\%, O'Farrell et al., 2001). The other component of calving interval, gestation length, has increased by approximately one day in Friesian cows mated to Friesian sires since records began (1979: 281 days; 2001: 282 days Department of Agriculture, Food and Rural Development, 1979 - 2001). Consequently, it is suggested that a lower conception rate (and, hence, longer calving-to-conception interval) is the primary component of a longer calving interval but there may also be a contribution from an increased calvingto-service interval.

\section{Calving pattern}

After the introduction of milk quotas (1984), there was a move away from winter/early spring-calving towards late springcalving, to maximise utilisation of grazed grass (Dillon et al., 1995). This may have contributed to higher culling for 'infertility' (Mee et al., 1999) as farmers had to adopt a more compact breeding season to have cows milking from the first day of April, the start of the new milk quota year. It is not known whether these changes in calving and breeding patterns accentuated any possible detrimental effect on dairy cow fertility exerted by the stress of turnout onto highly fertilised, low dry matter pasture. In beef heifer models, acute nutritional stress around AI has significantly reduced embryo survival (Dunne et al., 2001) but intake of high crude protein pasture has not (Kenny et al., 2001). The reproductive needs of a seasonal dairy industry with a compact breeding season may not be compatible with NAHF genetics, which originated in an all-year-roundcalving dairy industry.

Herd size

Increased herd size and greater numbers of cows per labour unit have frequently been cited as contributory factors to declining herd fertility (Lucy, 2001). The average Irish dairy herd size increased by $34 \%$ (Figure 7 ) in the 1990s (ICBF, 2002). 
However, a shortage of skilled labour has emerged as a more critical issue with a $17 \%$ drop in the farm labour force during the same decade (O'Donovan et al., 2000). In addition, parttime farming emerged as a significant trend in herd management on Irish farms during the 1990s. Reduced efficiency of detection of oestrus in large herds has been associated with inadequate attention to individual cows, insufficient time spent observing cows for oestrus, over-reliance on tail paint, and poor record keeping (Lucy, 2001). A factor analysis of data from Irish dairy herds from 1991 to 1998 showed a significant relationship between large herd size (and associated characteristics) and reduced calving rate (Fahey et al., 2002). Expanding and large herds are also more likely to maintain infectious agents that may cause reduced calving rates, such as bovine viral diarrhoea virus (Mee et al., 2002), Leptospira interrogans serovar hardjo (Leonard et al., 2002) and Salmonella spp (Mee et al., 2002). This infectious challenge may have been exacerbated by increased use (22\%) of bulls for breeding throughout the 1990s, possibly in order to reduce time spent detecting oestrus. Furthermore, with increases in herd size has come a move away from tie-up byre and strawbedded housing to cubicle housing, which may contribute towards a reduction in the expression of oestrus and in the productive lives of the cows.

Do-it-yourself artificial insemination (DIYAI)

The Department of Agriculture issued the first licences for herdowners or their whole-time employees to perform DIYAI in 1984. In 1991, approximately one third of inseminations in DairyMIS herds were conducted by DIYAI. By 1996, this had increased to almost half of all inseminations (O'Farrell and Crilly, 2001). This trend was confirmed nationally by the doubling in the number of DIYAI licences issued from 1992 to 2001 (ICBF, 2002). There has also been increased usage of DIYAI internationally (Washburn et al., 2002). In an Australian study (Morton, 2000) where professional and DIYAI technicians were compared in the same herds, the latter had a significantly lower conception rate (by 4\%). Examination of DairyMIS data from 1991 to 1996 showed that first service

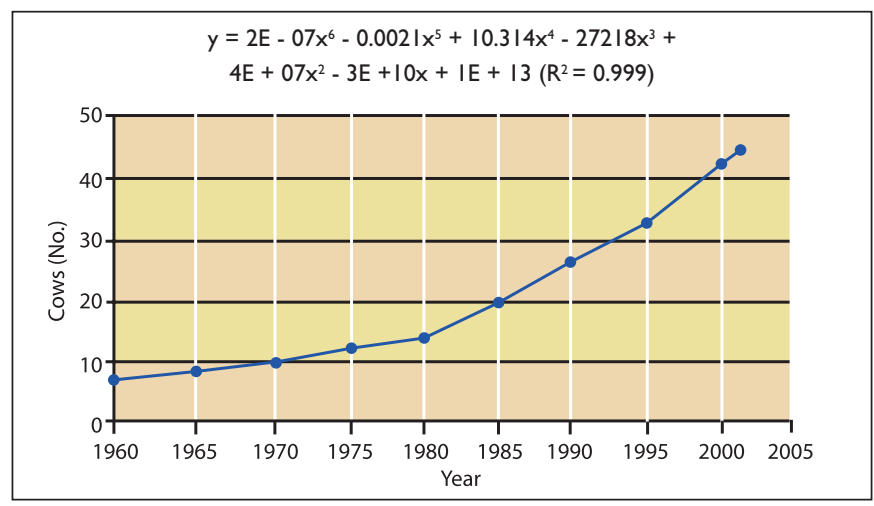

FIGURE 7: Average Irish dairy herd size between 1960 and 2001. (Sources: ICBF, 2002; EEC, 1977-200I). calving rate to DIYAI (48\%) was significantly lower than that of commercial AI (55\%) and overall first service calving rate declined over time. The decline in herd fertility in these herds was partially attributed to the increased use of DIYAI and the associated lower fertility (O'Farrell and Crilly, 2001). However, calving rates following DIYAI may be attributed to DIYAI per se or herd characteristics such as calving pattern, herd size and milk yield (Mee et al., 1999). Recent data (1999-2000) indicate no differences in conception rates between commercial and DIY operators in DairyMIS herds (Buckley et al., 2003b). Furthermore, the impact of DIYAI on herd fertility nationally is likely to be much less than that in DairyMIS herds as the proportion of farmers nationally using DIYAI is substantially lower (2,923 dairy and beef farmers licensed in 2001; ICBF, 2002).

Current fertility in Irish dairy herds

Given these trends in herd fertility, Teagasc embarked on a large-scale longitudinal study in 1999 to benchmark the reproductive performance of Irish commercial dairy herds. This ongoing study of 77 spring-calving herds has collected data on approximately 6,500 cows per year. Data were collected on management, nutrition, genetics, health and fertility with all herds enrolled in DairyMIS (Buckley et al., 2000). Results for fertility traits are shown in Table 2. Estimated 305-day milk yield averaged $6,570 \mathrm{~kg} / \mathrm{cow}$ in cows having $50 \%$ HolsteinFriesian genes. On average, herd fertility was below that required to achieve compact calving. However, the top quartile of herds on conception rate to first service achieved good herd fertility (conception rate to first service $59 \%$, infertile rate $11 \%$,

TABLE 2: Fertility traits in the Teagasc Farm Fertility Study (Source: Buckley et al., 2000)

\begin{tabular}{|c|c|c|}
\hline Fertility trait & Herd mean & Herd range \\
\hline \multicolumn{3}{|l|}{ Pre-breeding $^{a}$} \\
\hline Anovulation (\%) & 10 & $0-21$ \\
\hline Cystic ovaries (\%) & 3 & $0-10$ \\
\hline Subclinical endometritis (\%) & 24 & $8-38$ \\
\hline Pyometra (\%) & 2 & $0-8$ \\
\hline \multicolumn{3}{|l|}{ Breeding season } \\
\hline Calving-to-first service (days) & 71 & $59-92$ \\
\hline Calving-to-conception (days) & 88 & $73-103$ \\
\hline Submission rate $(21$-days $)(\%)^{b}$ & 70 & $25-96$ \\
\hline Conception rate to first service (\%) & 48 & $29-71$ \\
\hline Infertile rate $(\%)$ & 14 & $2-40$ \\
\hline Breeding season (weeks) & 15 & $9-25$ \\
\hline \multicolumn{3}{|c|}{$\begin{array}{l}\text { Determined by ultrasonography approximately one week before the date set } \\
\text { for the start of mating. }\end{array}$} \\
\hline \multicolumn{3}{|c|}{$\begin{array}{l}\text { b Percentage of calved cows submitted for service in the first } 21 \text { days } \\
\text { of the breeding season. }\end{array}$} \\
\hline
\end{tabular}


14-week breeding season). In a questionnaire survey, the majority of farmers replied that they followed recommended fertility management practices (Mee et al., 2002b). One of the primary risk factors associated with poor fertility was BCS loss (Buckley et al., 2003a). The conception rate described here $(48 \%)$ is consistent with recent reports from other dairy industries (Australia, 49\%, Morton, 2000; New Zealand, 53\%, $\mathrm{Xu}$ and Burton, 2000; Northern Ireland, 37\%, Mayne et al., 2002; North America, 45\%, Lucy, 2001; United Kingdom, 44\%, Esslemont and Kossaibati, 2002).

These trends were confirmed by an analysis of National Farm Survey data, which showed that in the year 2000 less than $10 \%$ of farmers calved $90 \%$ or more of their cows over a nine-week period (Donnellan et al., 2002). In conjunction with these studies, a recent large-scale study of Irish dairy herds showed an embryonic loss rate of $7 \%$ in pregnant heifers and cows between days 28 and 84 of gestation (Silke et al., 2002). The primary risk factor was BCS loss; cows that lost 0.5 of a BCS unit had a probability of 0.12 of embryonic mortality compared to a probability of 0.04 for cows which gained 0.5 of a BCS unit. This incidence of late embryonic mortality is considerably lower than that of early embryonic mortality $(30 \%)$ or late embryonic mortality reported in North America (20\%, Vasconcelos et al., 1997 ) but similar to that reported in New Zealand (4.5\%, Clark, 2001). Data from a recent longitudinal survey of twelve European countries comprising 143 dairy herds showed that, although both mean calving interval (394 days) and mean culling rate $(28 \%)$ were high, the Irish herds had below average calving interval, culling rate and milk yield (EDF, 2002).

Strategies are required to improve or halt the decline in reproductive performance as production systems are continually evolving. These approaches must include feeding systems to reduce negative energy balance and maintain body condition, automated management systems to improve detection of oestrus with less labour, and adoption of a total merit breeding index to select for genetically more fertile cattle. In the absence of research and progress in these areas, the response to traditional veterinary therapies may become increasingly diminished.

\section{Conclusions}

In Ireland, dairy herd fertility has declined over the past twenty years. The primary components of this decline have been a lower conception rate and an increased calving interval. These phenotypic trends can be attributed to both genetic and environmental factors and their interactions. Currently, dairy herd fertility falls short of the targets set for seasonal compact calving.

\section{References}

Berglund, B. and Philipsson, J. (2001). Breeding for fertility - the Scandinavian experience. Cattle Practice 9: 169-172.

Bloch, A., Wolfenson, D., Kaim, M., Roth, Z., Braw-Tal, R. and Folman, Y. (2001). Factors affecting the time intervals between estrus, LH surge and ovulation in high-yield dairy cows. Journal of Animal Science 79: Suppl. 1, 464-465.

Boichard, D., Barbat, A. and Briend, M. (2002). Bilan phenotypique de la fertilite chez les bovins laitiers. Reproduction Genetique et Performances, Compte rendu de la journee annuelle de l'Association pour l'Etude de la Reproduction Animale, Lyon, France, pp 5-9.

Britt, J.H. (1994). Follicular development and fertility: Potential impacts of negative energy balance. Proceeding of the National Reproduction Symposium, Pittsburgh, North America, ppl03-112.

Buckley, F., Dillon, P., Mee, J. F. and Veerkamp, R. (2000). Moorepark farm fertility study - initial results. Proceedings of the Irish Grassland Association Dairy Conference, Tullamore, Ireland, pp 24-37

Buckley, F., O'Sullivan, K., Mee, J.F., Evans, R.D. and Dillon, P. (2003a). Relationships among milk yield, body condition, cow weight, and reproduction in spring-calved Holstein-Friesians. Journal of Dairy Science 86: 2308-2319.

Buckley, F., Mee, J.F., O'Sullivan, K., Evans, R., Berry, D. and Dillon, P. (2003b). Insemination factors affecting conception rate in seasonal calving Holstein-Friesian cows. Reproduction Nutrition Development 43: (in press).

Burton, L.J., Harris, B.L., Winkelman, A.M. and Xu, Z.Z. (1999). Reproductive performance and genetic improvement of fertility in dairy cattle. Proceedings of the Dairy Farming Anmual Conference, Massey University, New Zealand, pp 59-67.

Chevalier, A. and Humblot, P. (1998). Evolution des taux de non retour apres insemination artificielle: effet du controle du delai de mise a la reproduction sur les resultats de fertilite. Rencontres Recherches Ruminants 5: 75-77.

Clark, B. (2001). "I thought she was pregnant": unfolding the mystery behind the long return interval NZ dairy cow. Proceedings of the Ruakura Dairy Farmers Conference, Hamilton, New Zealand, p 79.

Cromie, A. (2002). New body condition scoring proofs to improve fertility. Irish Farmers Journal, Winter AI Supplement, w/e 16 November, pp2-3.

Cunningham, E.P. (1976). Breed composition of the 1976 calf crop. Farm and Food Research 7: 16-17.

Department of Agriculture, Food and Rural Development (19792001). Reports on Progeny Test Results and Ease of Calving Survey Results. Dublin: Animal Breeding Division.

Dillon, P., Crosse, S., Stakelum, G. and Flynn, F. (1995). The effect of calving date and stocking rate on the performance of springcalving dairy cows. Grass and Forage Science 50: 286-299.

Dillon, P. and Veerkamp, R.F. (2001). Breeding strategies. Proceedings of the Teagasc National Dairy Conference, Killarney, Ireland, pp 41-54.

Donnellen, T., Dillon, P., Shalloo, L., Hennessy, T. and Breen, J. (2002). A dairy farming road map: where now for dairy farmers? Proceedings of the National Dairy Conference, Killarney, Ireland, pp 13-51.

Drennan, M. and Power, R. (1993). Breed composition of the national cattle herd. Farm and Food 3: 27-30. 
Dunne, L.D., Diskin, M.G., Boland, M.P., O'Farrell, K.J. and Sreenan, J.M. (2001). The effect of changes in feed intake around the time of insemination on systemic progesterone and embryo development and survival in cattle. Occasional Publication No.26British Society of Animal Science 2: 381-384.

EDF (2002). European Dairy Farmers Report. Edited by A. Reil. Braunschweig, Germany: Federal Agricultural Research Centre (FAL), Institute for Farm Economics and Rural Studies.

EEC (1977-2001). EEC Dairy Facts and Figures, Thames Ditton: Milk Marketing Board, UK (1997-1994) and London: The Dairy Council (2001).

Esslemont, D. and Kossaibati, M. (2002). Trends in fertility in 52 dairy herds over 11 seasons. In: The Costs of Poor Fertility and Disease in UK Dairy Herds. Milton Keynes: Intervet UK Limited. pp 21-42.

Evans, R.D., Buckley, F., Dillon, P. and Veerkamp, R.F. (2002). Genetic parameters for production and fertility in spring-calving Irish dairy cattle. Irish Journal of Agricultural and Food Research 41: 43-54.

Fagan, J.G. and Roche, J.F. (1986). Reproductive activity in postpartum dairy cows based on progesterone concentrations in milk or rectal examination. Irish Veterinary Journal 40: 124-131.

Fahey, J., O'Sullivan, K., Crilly, J. and Mee, J.F. (2002). The effect of feeding and management practices on calving rate in dairy herds. Animal Reproduction Science 74: 133-150.

Fair, T., Kelleher, D. and O'Farrell, K. (1991). Analysis of Moorepark fertility data. Report for the Department of Animal Science and Production, University College Dublin, pp 1-57.

Gorlach, A. (1988). Zur fruchtbarkeit beim rind aus der sicht eines sterilitatstierarztes. Der Praktische Tierarzt 69: 68-70.

Harris, B.L., Holmes, C.W., Winkelman, A.M. and Xu, Z.Z. (2001). Comparisons between fertility and survival of strains of Holstein-Friesian cows, Jersey cows and their crosses in New Zealand. Occasional Publication No.26 - British Society of Animal Science 2: 491-493.

Hoekstra, J., van der Lugt, A.W., van der Werf, J.H.J. and Ouweltjes, W. (1994). Genetic and phenotypic parameters for milk production and fertility traits in upgraded dairy cattle. Livestock Production Science 40: 225-232.

Horan, B., Mee, J.F., Dillon, P., Berry, D., O’Connor, P. and Rath, M. (2003). Comparison of reproductive performance of different strains of Holstein-Friesian cows managed under various pasture based systems of milk production. Proceedings of the Agricultural Research Forum, Tullamore, Ireland, p15.

ICBF (Irish Cattle Breeding Federation) (2002). Irish Cattle Breeding Statistics, 2001.

Jorritsma, R., Jorritsma, H., Schukken, Y.H. and Wentink, G.H. (2000). Relationships between fatty liver and fertility and some periparturient diseases in commercial Dutch dairy herds. Theriogenology 54: 1065-1074.

Jorritsma, R., de Groot, M.W., Vos, P.L.A.M., Kruip, T.A.M., Wensing, Th. and Noordhuizen, J.P.T.M. (2003a). Acute fasting in heifers as a model for assessing the relationship between plasma and follicular fluid NEFA concentrations. Theriogenology 60: 151161.

Jorritsma, R., Wensing, T., Kruip, T.A.M., Vos, P.L.A.M. and Noordhuizen, J.P.T.M. (2003b). Metabolic changes in early lactation and impaired reproductive performance in dairy cows. Veterinary Research 34: 11-26.

Kenny, D.A., Boland, M.P., Diskin, M.G. and Sreenan, J.M. (2001). Effect of pasture crude protein and fermentable energy supplementation on blood metabolite and progesterone concentrations and on embryo survival in heifers. Animal Science 73: 501-511.

Langley, O.H. (1986). Factors affecting reproductive performance of dairy cows. Moorepark 25th Anniversary Publication. Part II: Animal Health and Machine Milking. Dublin: An Foras Taluntais. pp 54-75.

Leonard, N., Mee, J.F., Snijders, S.E.M. and Mackie, D. (2002). Prevalence of anti-Leptospira antibodies in bulk milk in unvaccinated Irish dairy herds. Irish Veterinary Journal 55: 278.

Lopez-Gatius, F. (2003). Is fertility declining in dairy cattle? A retrospective study in northeastern Spain. Theriogenology 60: 89-99.

Lucy, M.C. (2001). Reproductive loss in high-producing dairy cattle: where will it end? Journal of Dairy Science 84: 1277-1293.

Mann, G.E., Lamming, G.E., Robinson, R.S. and Wathes, D.C. (1999). The regulation of interferon-t production and uterine hormone receptors during early pregnancy. Journal of Reproduction and Fertility, Supplement 54: 317-328.

Mann, G.E. (2002). Corpus luteum function and early embryonic death in the bovine. Proceedings of the World Buiatrics Congress, Hannover, Germany, pp 300-306.

Mayne, C.S., McCoy, M.A., Lennox, S.D., Mackey, D.R., Verner, M., Catney, D.C., McCaughey, W.J., Wylie, A.R.G., Kennedy, B.W. and Gordon, F.J. (2002). Fertility of dairy cows in Northern Ireland. Veterinary Record 150: 707-713.

McGrath, M.E., Mee, J.F., Snijders, S.E.M. and O'Callaghan, D. (2001). The effect of genotype on the onset of puberty and subsequent fertility in dairy heifers. Proceedings of the Agricultural Research Forum, Tullamore, Ireland, p 46.

Mee, J.F., Fahey, J. and Crilly, J. (1999). Breeding the dairy cow of the future - today's challenges. Proceedings of the Teagasc National Dairy Conference, Adare, Co. Limerick, Ireland, pp 7-16.

Mee, J.F., Waijer, A. and Heimstra, J. (2002a). Evaluation of a radio-telemetric oestrus detection system in dairy cows at pasture. Research Report, Teagasc Dairy and Pig Husbandry Departments, Moorepark, pp 16-17.

Mee, J.F., Moyes, T., Gleeson, D. and O'Brien, B. (2002b). A questionnaire survey of fertility management on dairy farms in the Republic of Ireland. Irish Veterinary Journal 55: 122-128.

More O'Ferrall, G.J. (1984). Holstein or Friesian for Irish dairy farmers? Farm and Food Research 15: 62-64.

Morton, J. (2000). The InCalf Project - some risk factors for reproductive performance in Australian dairy herds. Proceedings of the Australian and New Zealand Combined Dairy Veterinarians' Conference, Port Vila, Vanuatu, pp 43-61. 
Nebel, R.L. and Mowrey, C.M. (2000). Why is it so hard to catch cows in heat? Hoard's Dairyman 145: 550.

O'Donovan, K., O'Brien, B., Kinsella, J., Ruane, D. and Gleeson, D. (2000). Labour on dairy farms - the springtime challenge. Proceedings of the National Dairy Conference, Cork, Ireland, pp 7784.

O'Farrell, K.J. (1992). Management Factors Affecting the Reproductive Performance of Spring-Calving Dairy Cows in Ireland. Ph.D. Thesis, University of Dublin.

O'Farrell, K.J., Crilly, J., Sreenan, J.M. and Diskin, M. (1997). Is cow fertility declining on Irish dairy farms? Proceedings of the Teagasc National Dairy Conference, Fermoy, Ireland, pp 88-106.

O'Farrell, K.J. and Crilly, J. (2001). First service calving rates in Irish dairy herds: trends from 1991-1996. Occasional Publication No.26British Society of Animal Science 2: 353-358.

Opsomer, G., Grohn, Y.T., Hertl, J., Coryn, M., Deluyker, H. and de Kruif, A. (2000). Risk factors for post partum ovarian dysfunction in high producing dairy cows in Belgium: a field study. Theriogenology 53: 841-857.

Ouweltjes, W., Smolders, E.A.A., van Eldik, P., Elving, L. and Schukken, Y.H. (1996). Herd fertility parameters in relation to milk production in dairy cattle. Livestock Production Science 46: 221-227.

Pryce, J.E. and Veerkamp, R.F. (2001). The incorporation of fertility indices in genetic improvement programmes. Occasional Publication No.26 - British Society of Animal Science 1: 237-249.

Pryce, J.E., Simm, G. and Robinson, J.J. (2002). Effects of selection for production and maternal diet on maiden dairy heifer fertility. Animal Science 74: 415-421.

Quinn, E.P., Mee, J.F., Dillon, P.G., Gath, V. and Crowe, M.A. (2002). The reproductive performance of three strains of primiparous Holstein-Friesian cows managed under three grassbased systems of milk production. Proceedings of the Agricultural Research Forum, Tullamore, Ireland, p 72.

Quinn, N., Killen, L. and Buckley, F. (2003). The factors affecting the lactation curve of Irish dairy cows. Proceedings of the Agricultural Research Forum, Tullamore, Ireland, p 20.

Rajala-Schulz, P.J. and Fraser, G.S. (2003). Reproductive performance in Ohio dairy herds in the 1990s. Animal Reproduction Science 76: 127-142.

Royal, M.D., Darwash, A.O., Flint, A.P.F., Webb, R., Woolliams, J.A. and Lamming, G.E. (2000). Declining fertility in dairy cattle: changes in traditional and endocrine parameters of fertility. Animal Science 70: 487-501.

Sartori, R., Sartor-Bergfelt, R., Mertens, S.A., Guenther, J.N., Parrish, J.J. and Wiltbank, M.C. (2002). Fertilization and early embryonic development in heifers and lactating cows in summer and lactating and dry cows in winter. Journal of Dairy Science 85: 2803-2812.

Silke, V., Diskin, M.G., Kenny, D.A., Boland, M.P., Dillon, P.,
Mee, J.F. and Sreenan, J.M. (2002). Extent, pattern and factors associated with late embryonic loss in dairy cows. Animal Reproduction Science 71: 1-12.

Silva, H.M., Wilcox, C.J., Thatcher, W.W., Becker, R.B. and Morse, D. (1992). Factors affecting days open, gestation length, and calving interval in Florida dairy cattle. Journal of Dairy Science 75: 288-293

Simm, G. (1998). Genetic Improvement of Cattle and Sheep. Ipswich: Farming Press.

Snijders, S.E.M., Dillon, P., O'Callaghan, D. and Boland, M.P. (2000). Effect of genetic merit, milk yield, body condition and lactation number on in vitro oocyte development in dairy cows. Theriogenology 53: 981-989.

Snijders, S.E., Dillon, P.G., O'Farrell, K.J., Diskin, M., Wylie, A.R., O'Callaghan, D., Rath, M. and Boland, M.P. (2001). Genetic merit for milk production and reproductive success in dairy cows. Animal Reproduction Science 65: 17-31.

Taylor, V.J., Beever, D.E. and Wathes, D.C. (2000). Plasma IGF-I, energy balance status and ovarian function in dairy cows producing average and high milk yields in the early post partum period. Journal of Reproduction and Fertility Abstract Series No. 26: 34-35.

Vasconcelos, J.L.M., Silcox, R.W., Lacerda, J.A., Pursley, J.R. and Wiltbank, M.C. (1997). Pregnancy rate, pregnancy loss and response to heat stress after AI at two different times from ovulation in dairy cows. Biology of Reproduction 56, Supplement 1 (Abstract 230): 140.

Veerkamp, R.F., Oldenbroek, J.K., Van Der Gaast, H.J. and Van Der Werf, J.H.J. (2000). Genetic correlation between days until start of luteal activity and milk yield, energy balance, and live weights. Journal of Dairy Science 83: 577-583.

Washburn, S.P., Silvia, W.J., Brown, C.H., McDaniel, B.T. and McAllister, A.J. (2002). Trends in reproductive performance in Southeastern Holstein and Jersey DHI herds. Journal of Dairy Science 85: 244-251.

Weller, J.I. and Ezra, E. (1997). Genetic analysis of somatic cell score and female fertility of Israeli Holsteins with an individual animal model. Journal of Dairy Science 80: 585-593.

Westwood, C.T., Lean, I.J. and Garvin, J.K. (2002). Factors influencing fertility of Holstein dairy cows: a multivariate description. Journal of Dairy Science 85: 3225-3237.

Whitaker, D.A. (2002). What to do about modern dairy cows and fertility? Irish Veterinary Journal 55: 635-638.

Wiltbank, M.C., Fricke, P.M., Sangsritavong, S., Sartori, R. and Ginther, O.J. (2000). Mechanisms that prevent and produce double ovulations in dairy cattle. Journal of Dairy Science 83: 29983007.

Xu, Z. and Burton, L. (2000). Reproductive performance of dairy cows in New Zealand. Proceedings of the Australian and New Zealand Combined Dairy Veterinarians' Conference, Port Vila, Vanuatu, pp 23-41 


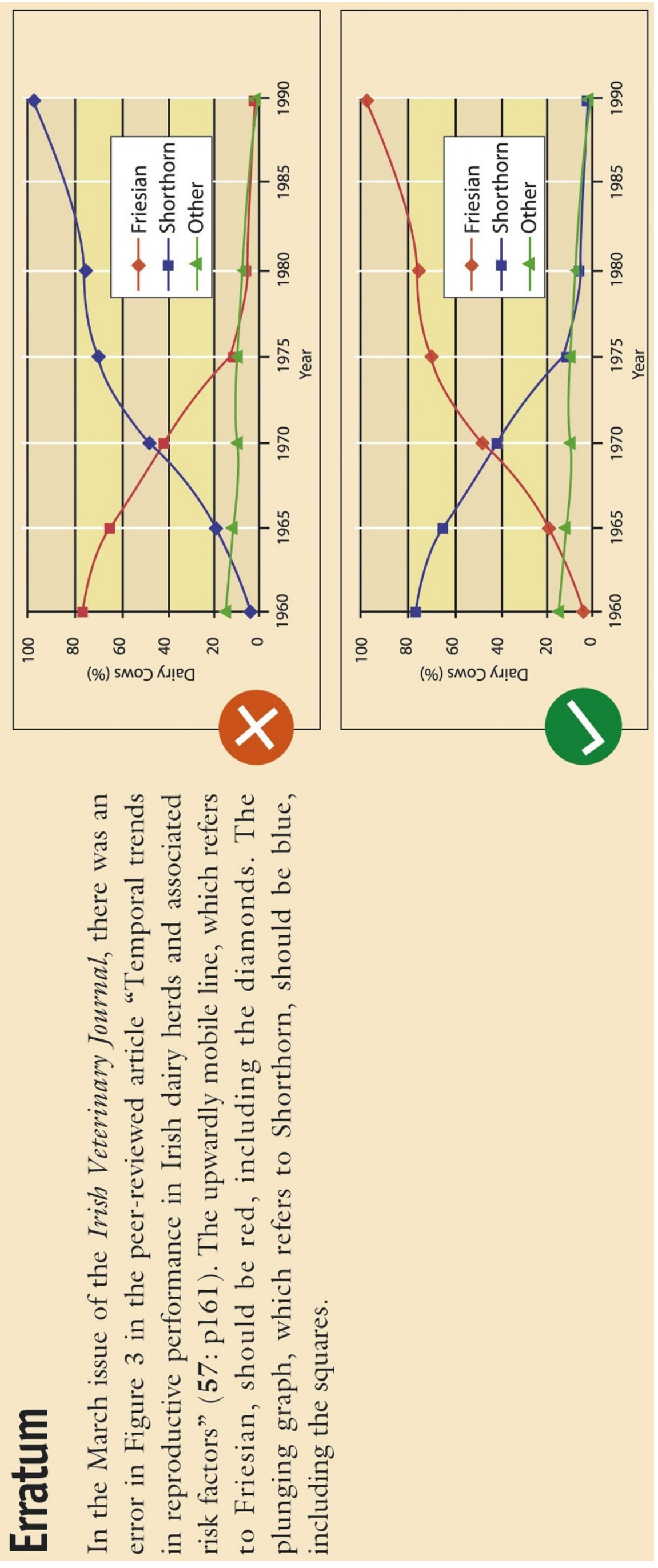

